\title{
Reduction of Emission Gas Concentration from Coal Based Thermal \\ Power Plant using Full Combustion and Partial Oxidation System
}

DOI:10.36909/jer.11927

Kalidasan B*, Deepika K ${ }^{* *}$, R Shankar ${ }^{* * *}$, A K Pandey ${ }^{* * * *}$, Syed Shahabuddin ${ }^{* * * * *}$, Richa

Kothari $^{* * * * * *}$, Priyank Agarwal ${ }^{* * * * * * *}$, Kamal Sharma ${ }^{* * * * * * * *}$

*Research Centre for Nano-Materials and Energy Technology (RCNMET), School of Science and Technology, Sunway University, No. 5, JalanUniversiti, Bandar Sunway, Petaling Jaya, 47500 Selangor Darul Ehsan, Malaysia

** Department of Biotechnology, Bannari Amman Institute of Technology, Sathyamangalam638401, Tamilnadu, India

***Energias De Renovables, UNAM, Temexico, Mexico

${ }^{* * * *}$ Research Centre for Nano-Materials and Energy Technology (RCNMET), School of Science and Technology, Sunway University, No. 5, JalanUniversiti, Bandar Sunway, Petaling Jaya, 47500 Selangor Darul Ehsan, Malaysia

${ }^{* * * * * *}$ Department of Science, School of Technology, Pandit Deendayal Petroleum University, Knowledge Corridor, Raisan Village, Gandhinagar-382007 Gujarat, India

${ }^{* * * * * * *}$ Department of Environmental Sciences, Central University of Jammu, Samba-18001, Jammu \& Kashmir, India.

********Energy Division, Mechanical Engineering, VIT University, Vellore-632014, Tamilnadu, India

********Department of Mechanical Engineering, Institute of Engineering and Technology, GLA University, Mathura, 281406, India

*Email: kalidasancinna@gmail.com; Corresponding Author 


\begin{abstract}
Rapid growth in industrialization has led to high dependency of reliable electric power source for its operation. On the contrary, thermal power plants expel pollutants consisting of hazardous gases that result in degradation of environment and ecosystem. Thus, utmost importance is to generate clean and efficient energy from power plant. This current article resolves the problem of sustainable power production using coal-based thermal power plants, by integrating gasification technologies to the system. The performance of thermal power plant in terms of emission is numerically analyzed with varying gasifier pressure, airfuel ratio, steam-fuel ratio and flue gas-fuel ratio. Numerical simulation of the gasification cycle with varying parameters is carried out using MATLAB. Optimum performance at gasifier pressure of 2 bar and the steam-fuel ratio of 0.25 was observed with relative air-fuel of 0.075 . With increasing flue gas-fuel ratio from 0.25 to 1.00 , although the mole fractions of components of syngas don't differ much, the heating value and cold-gas efficiency of syngas produced decreases for each fuel. Considering the emissions, simulated results present cogasification as better option over conventional systems. A reduction of two-third in $\mathrm{kg}$ of $\mathrm{CO}_{2}$ released per $\mathrm{kg}$ of fuel was observed with almost three-fourth decrement in $\mathrm{kg}$ of $\mathrm{CO}_{2}$ per $\mathrm{kWh}$ of power produced. Also, zero $\mathrm{SO}_{\mathrm{x}}$ and $\mathrm{NO}_{\mathrm{x}}$ emissions were observed compared to coal based thermal power plants. It is noted that optimum performance of gasification system at gasifier pressure of 2 bar, air-fuel ratio of 0.1 , steam-fuel ratio of 0.25 and flue gas-fuel ratio of 1.00. The proposed cycle presents itself suitable for further research and its application to coal based thermal power plants, providing potential towards supplementary power generation and cleaner exhaust. This research would also significantly contribute to achieve sustainable development goals.
\end{abstract}

Keywords: emission; flue-gas; gasification; steam-fuel ratio; temperature. 


\section{NOMENCLATURE}

$\begin{array}{ll}\mathrm{a}, \mathrm{b}, \mathrm{d}, \mathrm{f}, \mathrm{g}, \mathrm{h}, \mathrm{k} & \text { coefficients } \\ \mathrm{h} & \text { specific enthalpy, } \mathrm{kJ} / \mathrm{kg} \text { mol } \\ \mathrm{K} & \text { dissociation constant } \\ \mathrm{m} & \text { mass flow, } \mathrm{kg} / \mathrm{s} \\ \mathrm{T} & \text { temperature, } \mathrm{K} \\ \mathrm{P} & \text { gasifier pressure } \\ \mathrm{R} & \text { universal gas constant } \\ \Delta G^{o} & \text { Gibb's free energy }(\mathrm{kJ} / \mathrm{kg}-\mathrm{mol})\end{array}$


GRAPHICAL ABSTRACT

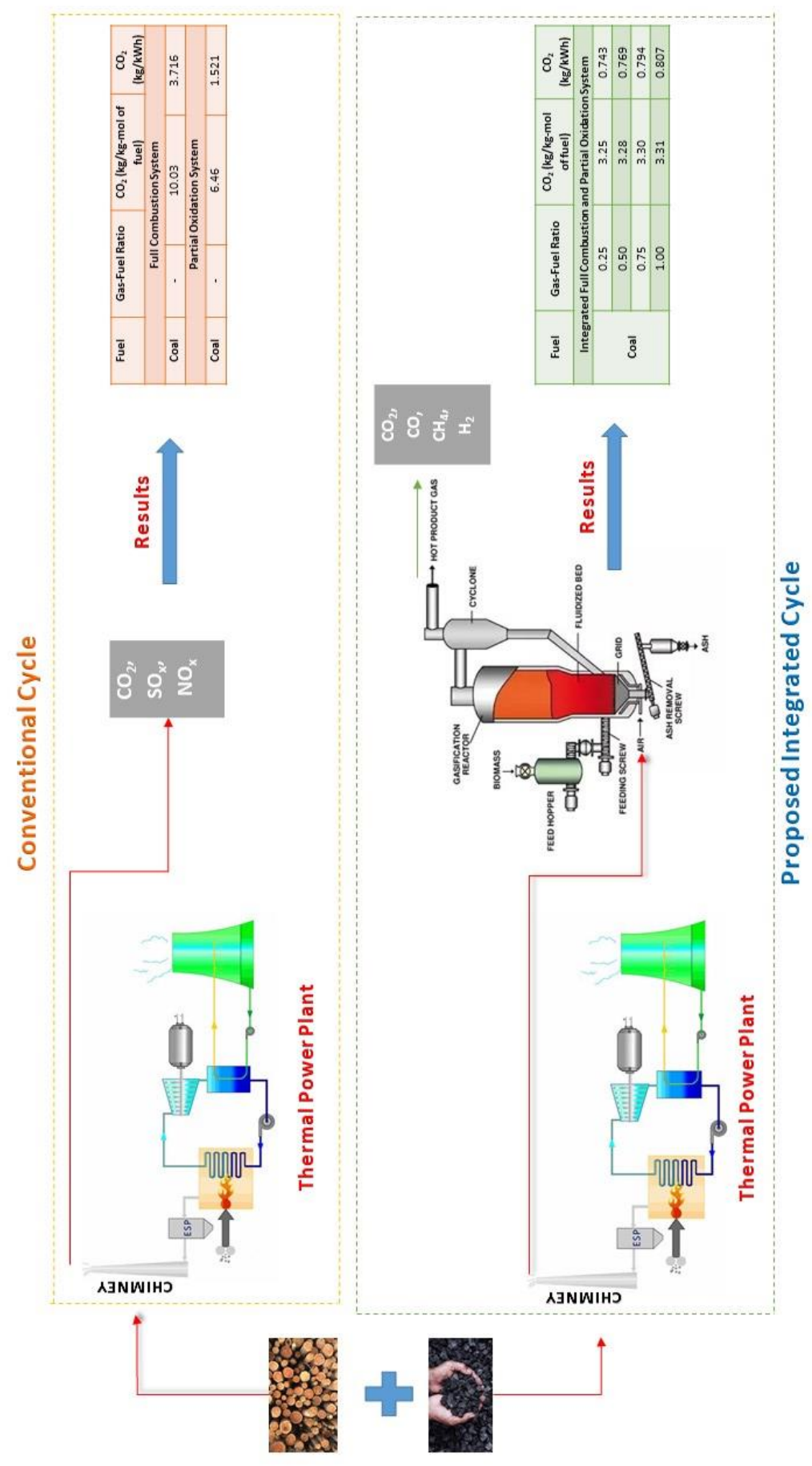




\section{INTRODUCTION}

Growth in population and industrialization has lead to high demand of electric power. Especially in few parts of the world, in order to bridge the gap between demand and supply of energy, increasing trends towards utilization of renewable energy is noted. Such renewable sources of power include solar energy, wind energy and biomass energy. However, the intermittent nature of supply for solar energy is one of the major disadvantages. Thus, electricity from fossil fuelled power plants has been the key source of energy and power for most of the developing countries like the India. The Indian power sector is caught between the pressure of adding new generating capacities to match the rapid growing demand of power and the environmental challenges encompassing power generation itself. And, the coal based power generation will continue to dominate its role in future till the time when other energy sources have not yet succeeded to take its place.

On the other hand, gasification process offers more scope for recovering products from waste than incineration. Gasification can meet concerns of global warming and aid in pollution control, multi-fuel capacity and energy conservation to achieve sustainable progression (Rezaiyan et al., 2005). Research analysis for both gasification and co-gasification of biomass waste, with varied composition were performed Biomass Integrated Gasification Combined Cycle (BIGCC) technology has the potential to produce electricity at a higher efficiency through the use of combustion turbines and steam turbines (Lapuerta et al., 2008). Gasification technique also finds its application in paper mills (Pio et al., 2020), sugarcane ethanol (Machin et al., 2021) industries and corn ethanol process industries. Gasification of Argentinean coal chars with carbon dioxide and oxygen investigated by (Ochoa et al., 2001 \& Gutierrez et al., 1987) presents the reaction kinetics and reactivity of gasification with $\mathrm{CO}_{2}$ by thermo-gravimetric for temperatures between 1173 and $1433 \mathrm{~K}$, and for $\mathrm{CO}_{2}$ concentrations 
among 50\% and 70\% v/v was done by (Micco et al., 2010). The authors obtained syngas with high calorific value of $190 \mathrm{~kJ} / \mathrm{mol}$. Research on co-gasification techniques and principles were performed and results conveyed that co-gasification is much efficient than conventional gasification systems (Brar et al., 2012). The developmental analysis of rice husk based Integrated Gasification Combined Cycle (IGCC) system with gas turbine by (Srinivas et al., 2012) presents the advantage of reduced emissions with combined cycles. Following the same principle, the concept of integrated full combustion and partial oxidation systems has been presented.

Coal gasification and coking to methanol (CGCTM) with DMR (dry methane reforming) technology was adopted to improve the carbon conversion and reduce the emission of $\mathrm{CO}_{2}$ (Chen et al. 2019). Advances integrate coal gasification combined cycle with triple bed combined circulating fluidized bed (TBCFB) model was developed by (Furusawa et al., 2019). In which, the cold gas efficiency (CGE) and heating value was high when compared to IGCC system. The findings also reports the increasing the temperature negatively affect the CGE. A new gasification process for cleaner combustion of coal, the process includes the combination of circulating fluidized preheater with down flow bed gasifier was proposed (Liang et al. 2018). They also reported that lowering the temperature of gasifier improves the cold gas efficiency and negatively affects the oxygen demand. Experimental study on pilot scale 8 t/d CFB gasifier was carried out (Wang et al., 2019). In this work, staging injection of AGA is carried out for the unburned solid particles filtered in cyclone separated at $3.75 \mathrm{~m}$, $6.25 \mathrm{~m}$ and $8.75 \mathrm{~m}$. It was noted that when solid particle are fed at height of $6.25 \mathrm{~m}$ there is a significant increase in cold gas efficiency, gas production. Integrated BIGCC with oxy-fuel combustion to reduce the $\mathrm{CO}_{2}$ emission was proposed (Xiang et al., 2019). Syngas produced from the gasifier is further burned in the oxy-fuel combustion chamber for power generation and the flue gas emitted is processed for $\mathrm{CO}_{2}$ capturing by cooling. A numerical investigation 
on radiation and gas property of the particles in order to predict the formation of $\mathrm{NO}_{\mathrm{x}}$ pollutants in pulverised coal was carried (Huynh et al., 2019).

A numerical system comprising of two reactors to enhance the potential of copper oxides for chemical looping gasification (CLG) was proposed (Sarafraz et al., 2017a). In the system copper oxide was used as oxygen carrier to improve syngas production. It was observed that $\mathrm{H}_{2} / \mathrm{CO}$ decreased slight with increase in operating temperature due to increase in $\mathrm{CO}$ production. The performance of different liquid oxygen carrier for a chemical looping combustion and chemical looping gasification system, by varying exergy flow, energy flow and syngas quality was assessed (Sarafraz et al. 2017b). CLG with liquid bismuth oxide for producing syngas was analyzed chemically and thermally by (Sarafraz et al. 2019). In the proposed method feed stock is considered as input and it's partially oxidized using molten bismuth in gasification reactor and it was followed by oxidation with air in air reactor. A solar thermo-chemical cycle depended coal liquefaction method for producing oil was proposed (Kong et al., 2019). Here the traditional coal liquefaction method for hydrogen generation is swapped by thermochemical cycling method. Thermodynamic simulation model integrated with LCA to find the environmental consequence of supercritical coal fired power plant of $1000 \mathrm{MW}$ operating under partial and low loads was modelled (Han et al., 2019). GSE software was opted for thermodynamic simulation and SimaPro for LCA investigation. It is pragmatic from the results that power plant operating at low power load about $30 \%$ resulted in rapid increase of environmental impact upto $90 \%$ due to low thermal and $\mathrm{NO}_{\mathrm{x}}$ removal efficiency. Catalyatic coal gasification process for the preparation of methane was reviewed in detail considering the effects of catalyst, their properties and composition and the preparation methods (Li et al., 2021). Research work has also been progressed with study on underground coal gasification technique with effect of temperature and pressure in the formation of hydrogen and methane (Hu et al., 2021) 
Numerous works has been carried out, by the researchers for reducing the emission from thermal power plant using integrated gasification technologies. In the present work, coal based thermal power plant has been integrated with circulating fluidised bed gasification system. Above literature highlights the application of gasification process to biomass waste, sugarcane ethanol, corn ethanol and rice husk. Few literatures consolidate the coal gasification with dry methane reforming and few other researches focused on chemical looping gasification with numerical analysis rather than experimentation. This research paper focus on integrating coal based thermal power plant with gasification cycle in order to determine the optimized condition for better cold gas efficiency along with complete reduction of $\mathrm{NO}_{\mathrm{x}}$ and $\mathrm{SO}_{\mathrm{x}}$ for cleaner emission using MATLAB. The conventional gasification system and the integrated cycle were analysed considering coal as fuel. The Table 1 shows the cold gas efficiency for the present work compared to the previous research with different biomass. The effects of relative air-fuel ratio, steam-fuel ratio, flue gas-fuel ratio and gasifier pressure on mole fraction of gases produced during gasification, gasifier temperature, heating value of syngas, and cold gas efficiency of gasifier have been studied.

Table 1: Cold Gas Efficiency of Previous Research Work

\begin{tabular}{|c|c|c|c|c|c|c|c|}
\hline \multirow{2}{*}{ Reference } & \multirow{2}{*}{ Biomass } & \multicolumn{5}{|c|}{$\begin{array}{c}\text { Gas Composition (\% by } \\
\text { Volume) }\end{array}$} & \multirow{2}{*}{$\begin{array}{c}\text { Cold Gas } \\
\text { Efficiency (\%) }\end{array}$} \\
\hline & & $\mathrm{CO}$ & $\mathbf{H}_{2}$ & $\mathrm{CH}_{4}$ & $\mathrm{CO}_{2}$ & $\mathbf{N}_{2}$ & \\
\hline $\begin{array}{c}\text { (Corella \& Toledo, } \\
\text { 2008) }\end{array}$ & Saw dust & 19.48 & 18.89 & 3.96 & - & - & 62.5 \\
\hline (Bridgwater, 2003) & Wood Chips & 26.5 & 7.0 & 2.0 & - & - & 48.7 \\
\hline (Warnecke, 2000) & Hazelnut Shells & 16.8 & 14.12 & 1.70 & - & - & 51.5 \\
\hline Present Work & Coal & 49 & 34 & 0.2 & 9.7 & 6.1 & 63.0 \\
\hline
\end{tabular}




\section{EXPERIMENTAL METHODS}

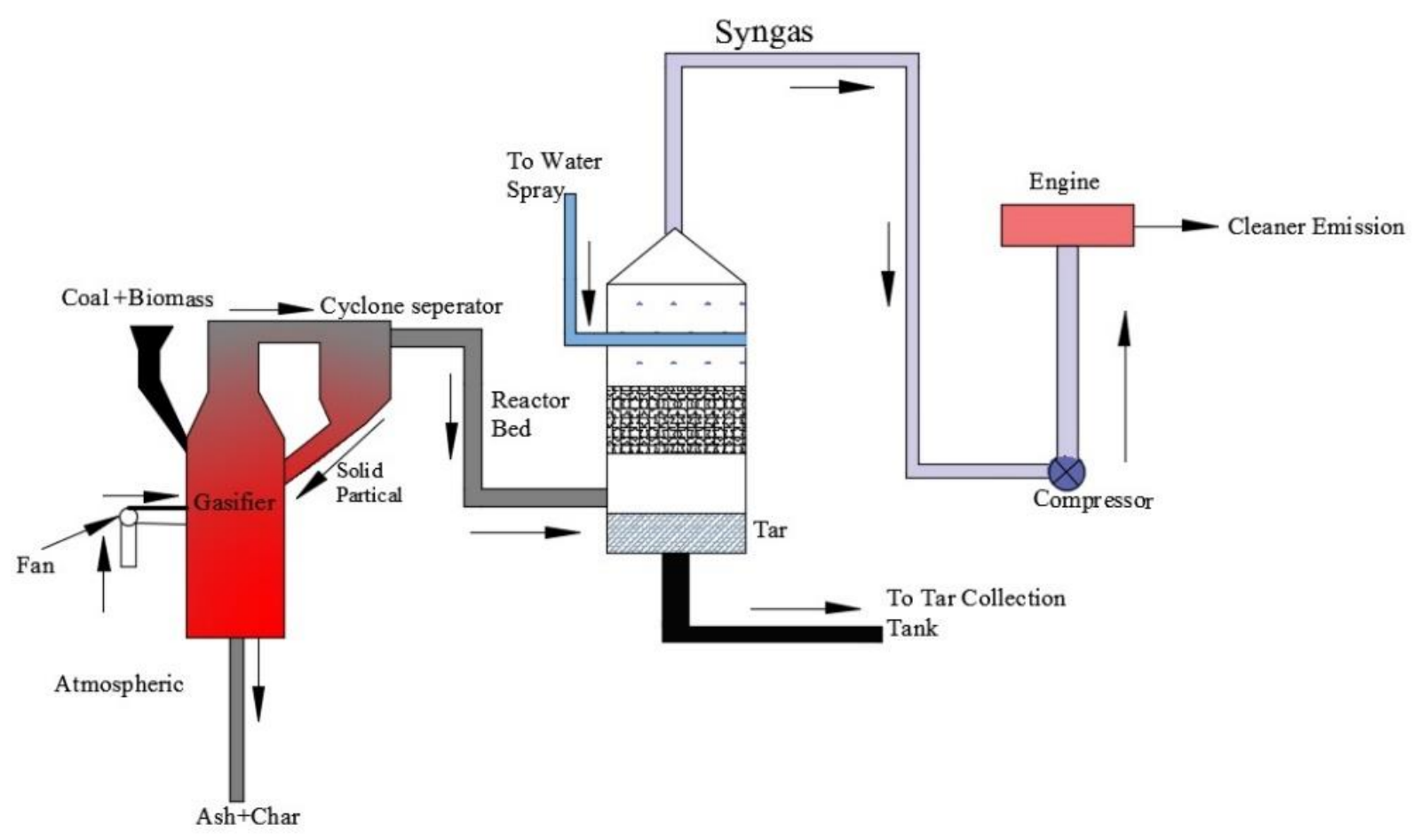

Figure 1 Gasification Process Cycle

Layout of gasification process cycle considered for numerical simulation is presented in Figure 1. Numerical simulation of the cycle is done using MATLAB. In the gasification layout coal and biomass are burned in a gasifier in the presence of air, the gas is then filtered in a cyclone separated to remove solid particles, the solid particles are sent back to the gasifier for complete combustion. Ash and char are extracted from the bottom of gasifier. Gas from cyclone separator is passed through a reactor in which water is sprayed for converting the flue gas into syngas. The syngas obtained is compressed and used in engine, which results in cleaner emission with less $\mathrm{NO}_{\mathrm{x}}$ and $\mathrm{SO}_{\mathrm{x}}$.

Proposed Integrated full combustion and partial oxidation cycle is presented in Figure 2. With combustion of coal in the boiler, flue gas rises and passes through various components resulting to generation on highly pressurized superheated steam that rotates turbine and the coupled generator. Passing through the air-preheater, flue gas heads towards electrostatic precipitator and then enters the gasification chamber at a temperature of about $150{ }^{\circ} \mathrm{C}$. The 
air-flue gas circuit of the full combustion process ends with the electrostatic precipitator, but results to deficient amount of oxygen for gasification. To makeover the deficient oxygen, auxiliary fan provides additional air into the gasifier that facilitates gasification similar to the above cycle.

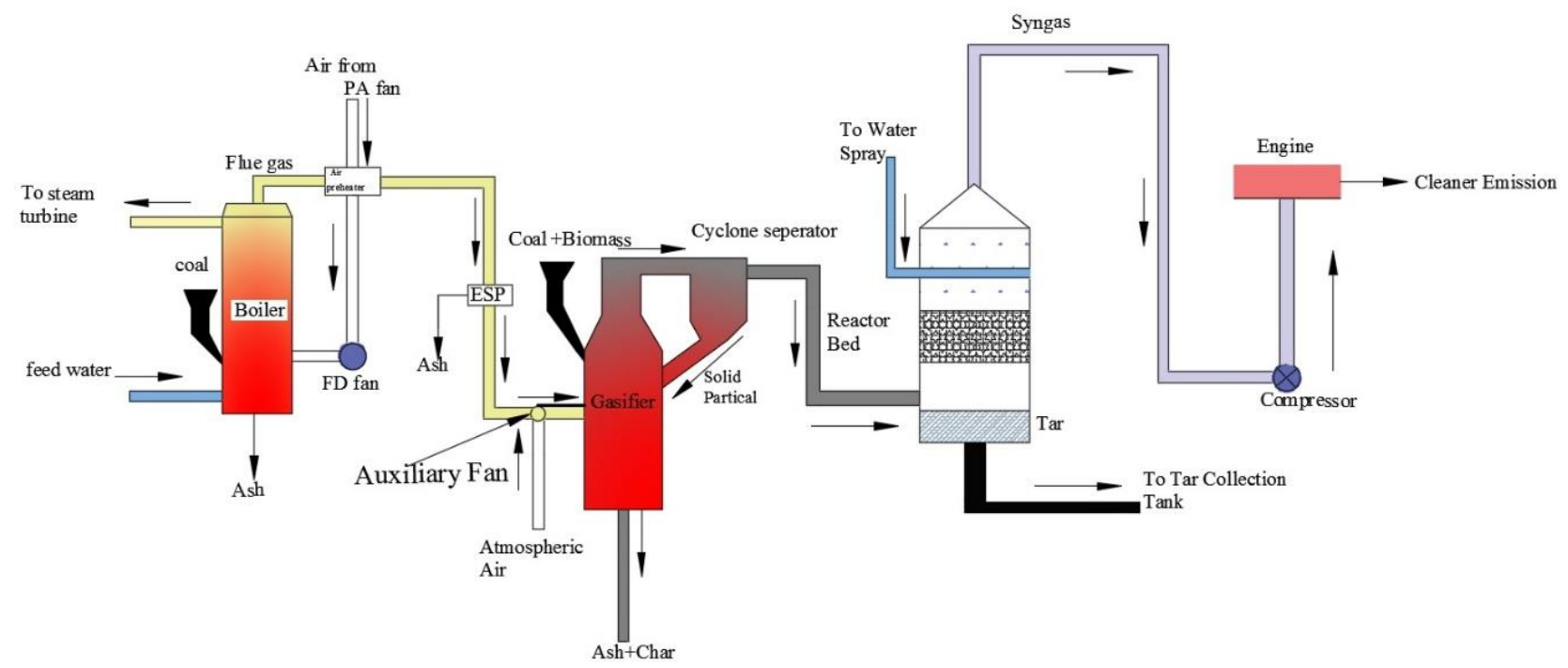

Figure 2 Proposed integrated full combustion and partial oxidation cycle.

\section{NUMERICAL METHOD}

For simulation based analysis of complete combustion of fuel, reactions (1) and (2) were used. Reaction (1) presents the combustion reaction for stoichiometric combustion, with no oxygen content after combustion. Reaction (2) presents the combustion reaction when excess is fed into the combustion chamber. Both (1) and (2) were solved using the energy balance method. Considering the combustion temperature of $1673 \mathrm{~K}$, the air-fuel ratio was determined to be 19.543 while the stoichiometric air-fuel ratio was found to be 10.126 .

$$
\begin{aligned}
& \mathrm{C}_{a 1} \mathrm{H}_{a 2} \mathrm{O}_{a 3} \mathrm{~N}_{a 4} \mathrm{~S}_{a 5}+x_{s}\left(a_{6} \mathrm{O}_{2}+a_{7} \mathrm{~N}_{2}\right) \Rightarrow b_{1} \mathrm{CO}_{2}+b_{2} \mathrm{H}_{2} \mathrm{O}+b_{3} \mathrm{~N}_{2}+b_{4} \mathrm{SO}_{2} \\
& \mathrm{C}_{a 1} \mathrm{H}_{a 2} \mathrm{O}_{a 3} \mathrm{~N}_{a 4} \mathrm{~S}_{a 5}+x\left(a_{6} \mathrm{O}_{2}+a_{7} \mathrm{~N}_{2}\right) \Rightarrow b_{1} \mathrm{CO}_{2}+b_{2} \mathrm{H}_{2} \mathrm{O}+b_{3} \mathrm{~N}_{2}+b_{4} \mathrm{SO}_{2}+b_{5} \mathrm{O}_{2}
\end{aligned}
$$


The model of the present numerical analysis is taken from the analysis performed by Srinivas et al. 2009. The generic formula of the fuel is given as $\mathrm{C}_{\mathrm{a} 1} \mathrm{H}_{\mathrm{a} 2} \mathrm{O}_{\mathrm{a} 3} \mathrm{~N}_{\mathrm{a} 4} \mathrm{~S}_{\mathrm{a} 5}$. Considering each solitary mole of a fuel, the coefficients a1, a2, a3, a4 and a5 are determined through ultimate analysis. Every single atom of carbon in fuel (coefficient a1) becomes one; similarly (coefficient a1, a2, a3, a4 and a5) are H/C, O/C, N/C and S/C mole ratio. The author (srinivas et al. 2009) neglects only the moisture content present in the coal sample; all other parameters are taken into consideration for the numerical study.

Reaction (3) presents the chemical reaction in gasifier with air, while (4) presents the reaction in gasifier employing exhaust flue gas from combustion systems. For reaction (4), coefficients $\mathrm{a}_{7}, \mathrm{a}_{8}, \mathrm{a}_{9}, \mathrm{a}_{10}$ and $\mathrm{a}_{11}$ are determined using the products obtained from combustion reaction (3.10) and making up their sum to single mole. Coefficient $\mathrm{a}_{6}$ for the reactions (3) and (4) is procured by variation in relative air-fuel ratio. Analysis was done considering one kg-mol of flue gas input and $a_{11}$ was varied which gives the relative gas-fuel ratio for equation (4).

$$
\begin{gathered}
\left(\mathrm{C}_{a 1} \mathrm{H}_{a 2} \mathrm{O}_{a 3} \mathrm{~N}_{a 4} \mathrm{~S}_{a 5}\right)_{\text {fuel }}+\left(a_{6}\left(a_{7} \mathrm{O}_{2}+a_{8} \mathrm{~N}_{2}\right)\right)_{\text {air }}+\left(a_{9} \mathrm{H}_{2} \mathrm{O}_{g}\right)_{\text {steam }}+\left(a_{10} \mathrm{H}_{2} \mathrm{O}_{l}\right)_{\text {moisture }} \\
\Rightarrow d_{1} \mathrm{CH}_{4}+d_{2} \mathrm{CO}+d_{3} \mathrm{CO}_{2}+d_{4} \mathrm{H}_{2}+d_{5} \mathrm{H}_{2} \mathrm{O}+d_{6} \mathrm{~N}_{2}+d_{7} \mathrm{SO}_{2} \\
\left(\mathrm{C}_{a 1} \mathrm{H}_{a 2} \mathrm{O}_{a 3} \mathrm{~N}_{a 4} \mathrm{~S}_{a 5}\right)_{\text {fuel }}+\left(a_{6}\left(a_{7} \mathrm{O}_{2}+a_{8} \mathrm{~N}_{2}\right)\right)_{\text {air }}+\left(a_{9} \mathrm{H}_{2} \mathrm{O}_{g}\right)_{\text {steam }}+\left(a_{10} \mathrm{H}_{2} \mathrm{O}_{l}\right)_{\text {moisture }} \\
+a_{11}\left(a_{12} \mathrm{CO}_{2}+a_{13} \mathrm{H}_{2} \mathrm{O}+a_{14} \mathrm{~N}_{2}+a_{15} \mathrm{SO}_{2}+a_{16} \mathrm{O}_{2}\right)_{\text {flue gas }} \\
\Rightarrow f_{1} \mathrm{CH}_{4}+f_{2} \mathrm{CO}+f_{3} \mathrm{CO}_{2}+f_{4} \mathrm{H}_{2}+f_{5} \mathrm{H}_{2} \mathrm{O}+f_{6} \mathrm{~N}_{2}+f_{7} \mathrm{SO}_{2}
\end{gathered}
$$

Taking atom balance on $\mathrm{C}, \mathrm{H}, \mathrm{O}$ and $\mathrm{N}$ for both the reactions (3) and (4), total of six unknowns and four equations were obtained. Thus, using the methane reforming reaction (15) \& water shift reaction (16), the dissociation constants, $\mathrm{k} 1$ and $\mathrm{k} 2$ were obtained. As well $\mathrm{k}_{1}^{\prime}$, $\mathrm{k}_{1}^{\prime \prime}, \mathrm{k}_{2}^{\prime}$ and $\mathrm{k}_{2}^{\prime \prime}$ represent the first and second derivative of dissociation constant for reforming reaction and water shift reaction.

From reaction (3):

C balance: $a_{1}=d_{1}+d_{2}+d_{3}$ 
$\mathrm{N}$ balance: $a_{4}+2 a_{6} a_{8}=2 d_{6}$

S balance: $a_{5}=d_{7}$

O balance: $a_{3}+2 a_{6} a_{7}+a_{9}+a_{10}=d_{2}+2 d_{3}+d_{5}+2 d_{7}$

H balance: $a_{2}+2 a_{9}+2 a_{10}=4 d_{1}+2 d_{4}+2 d_{5}$

From reaction (4):

C balance: $a_{1}+a_{11} a_{12}=f_{1}+f_{2}+f_{3}$

N balance: $a_{4}+2 a_{6} a_{8}+2+a_{11} a_{14}=2 f_{6}$

S balance: $a_{5}+a_{11} a_{15}=f_{7}$

O balance: $a_{3}+2 a_{6} a_{7}+a_{9}+a_{10}+2 a_{11} a_{12}+2 a_{11} a_{13}+2 a_{11} a_{15}+2 a_{11} a_{16}=f_{2}+2 f_{3}+f_{5}+2 f_{7}$

H balance: $a_{2}+2 a_{9}+2 a_{10}+2 a_{11} a_{13}=4 f_{1}+2 f_{4}+2 f_{5}$

Rearranging all the equations from (5) to (14), the equations were brought in terms of $\mathrm{a}_{1}, \mathrm{a}_{2}$, $a_{3}, a_{4}, a_{5}, a_{6}, a_{7}, a_{8}, a_{9}, a_{10}, d_{1}, d_{2}, d_{3}, d_{4}, d_{5}, d_{6}$ and $d_{7}$ for equation (3) and in terms of $a_{1}, a_{2}, a_{3}$, $a_{4}, a_{5}, a_{6}, a_{7}, a_{8}, a_{9}, a_{10}, a_{11}, a_{12}, a_{13}, a_{14}, a_{15}, a_{16}, f_{1}, f_{2}, f_{3}, f_{4}, f_{5}, f_{6}$ and $f_{7}$ for equation (4). Here, all parameters of $\mathrm{a}, \mathrm{d}, \mathrm{f}$ are constants.

$$
\begin{aligned}
& \mathrm{CH}_{4}+\mathrm{H}_{2} \mathrm{O}=\mathrm{CO}+3 \mathrm{H}_{2} \\
& \mathrm{CO}+\mathrm{H}_{2} \mathrm{O}=\mathrm{H}_{2}+\mathrm{CO}_{2} \\
& k_{1}^{\prime}=\frac{P_{\mathrm{CO}} P^{3} \mathrm{H}_{2}}{P_{\mathrm{CH}_{4}} P_{\mathrm{H}_{2} \mathrm{O}}}=\frac{d_{2} d^{3}{ }_{4} P^{2}}{d_{1} d_{5} n_{t}{ }^{2}} \quad \text { (for equation 3) } \\
& k_{1}^{\prime \prime}=\frac{P_{\mathrm{CO}} P^{3} \mathrm{H}_{2}}{P_{\mathrm{CH}_{4}} P_{\mathrm{H}_{2} \mathrm{O}}}=\frac{f_{2} f^{3}{ }_{4} P^{2}}{f_{1} f_{5} n_{t}{ }^{2}} \quad \text { (for equation 4) } \\
& k_{2}^{\prime}=\frac{P_{\mathrm{CO}_{2}} P_{\mathrm{H}_{2}}}{P_{\mathrm{CO}} P_{\mathrm{H}_{2} \mathrm{O}}}=\frac{d_{3} d_{4}}{d_{2} d_{5}} \quad \text { (for equation 3) }
\end{aligned}
$$


$k_{2}^{\prime \prime}=\frac{P_{C O_{2}} P_{H_{2}}}{P_{C O} P_{H_{2} O}}=\frac{f_{3} f_{4}}{f_{2} f_{5}} \quad$ (for equation 4)

$\mathrm{P}$ in (18) and (19) is gasifier pressure and $\mathrm{n}_{\mathrm{t}}$ is total moles in products for each reaction (3) and (4). The equilibrium constant was given by:

$\ln (k)=\frac{-\Delta G^{o}}{R T}$

Using numerical method the constant $\mathrm{d}_{1}$ and $\mathrm{d}_{2}$, and $\mathrm{f}_{1}$ and $\mathrm{f}_{2}$ are solved. Approximate values are assumed from $b_{1}$ and $b_{2}$ to begin the iteration in numerical method technique.

$$
\begin{aligned}
& f_{o}+h \frac{\partial f}{\partial b_{1}}+k \frac{\partial f}{\partial b_{2}}=0 \\
& g_{o}+h \frac{\partial g}{\partial b_{1}}+k \frac{\partial g}{\partial b_{2}}=0
\end{aligned}
$$

$b_{1}$ and $b_{2}$ are replaced by $f_{1}$ and $f_{2}$, and $g_{1}$ and $g_{2}$ as per the equation. The numerical values obtained for the constant $\mathrm{h}$ and $\mathrm{k}$ indicates the degree of accuracy for the coefficients constant $b_{1}$ and $b_{2}$. If convergence doesn't occur for the required degree of accuracy, then iteration process is carried using new assumed values as given in (28) and (29).

$b_{1}=b_{1}+h$

$b_{2}=b_{2}+k$

\section{Statistical analysis}

Cold gas efficiency (CGE) is measure on the performance of converting process. It represents the energy preserved in the synthesis gas.

$$
\text { CGE }(\%)=\frac{\text { Heating value of Syn gas } * 100}{\text { Heating value in the fuel input }}
$$

Amount of energy liberated during complete combustion of biomass in presence of adequate oxygen is known as heating value. Compared to most of the fossil fuel used, heating value of coal is low on a volumetric basis as its density is very low. In the present research 
work, heating value is represented as lower heating value as moisture content is in gaseous state in the producer gas.

Using the above simulated model, the heating value of the produced gas is numerically obtained from MATLAB, as well the heating value in the coal and gas-fuel mixture decreases from $23104 \mathrm{~kJ} / \mathrm{kg}$-mol based on the percentage of flue gas mixed with fuel. Using the heating value of producer gas and heating value of gas-fuel mixture, cold gas efficiency is determined.

\section{RESULTS AND DISCUSSION}

The ultimate analysis data of the coal used as fuel in the present work is carbon $78.58 \%$, hydrogen $4.41 \%$, oxygen $13.24 \%$, nitrogen $1.52 \%$, sulphur $0.64 \%$, and ash content of $1.61 \%$ with enthalpy of $-23104 \mathrm{~kJ} / \mathrm{kg}-\mathrm{mol}$ (Eftekhari, 2012). The MATLAB based simulations were done considering $1 \mathrm{~kg}$-mol of fuel input. With varying air-fuel ratio, gasifier pressure and steam-fuel ratio, plots for mole fraction of components of syngas with gasification temperature were obtained. Figure 3 depicts the mole fraction of emission gas composition for gasification process with steam fuel ratio as 0.25 for gasifier pressure of 2,4,6,8 and 10 bars. Figure 3 (a) presents variation of mole fraction of $\mathrm{CH}_{4}$ in syngas produced after the gasification process of fuel, Figure 3 (b) presents variation of mole fraction of $\mathrm{CO}$, Figure 3 (c) present for $\mathrm{CO}_{2}$, and Figure 3 (d) presents variation for mole fraction of $\mathrm{H}_{2}$. With gasifier pressure, relative air-fuel ratio and steam-fuel ratio as varying parameters, the variation of mole fractions of gases with gasification temperature presents detailed information about the mole fraction of composition of gases emitted from coal based power plant (Tian et al., 2018). As steam fuel ratio is increased from 0.25 to 1.0 (results with highest mole fraction are shown) the amount of fuel supplied with steam generation decreases which proportionally reduces the mole fraction of syngas composition i.e. $\mathrm{CH}_{4}, \mathrm{CO}, \mathrm{CO}_{2}$, and $\mathrm{H}_{2}$ irrespective of the combustion process. Also, increment in steam fuel ratio affects the temperature of reactor 
bed. Increment in both relative air-fuel ratio and steam fuel ration decreases the mole fraction of methane, hydrogen and carbon monoxide due to excess supply of air with constant fuel, and most of the air combines with carbon resulting in formation of excess carbon dioxide with increase in relative air fuel ratio. This is justified by the concept that increased amount of air supply to gasifier increases the oxidation effect in fuel and thus there is increase in temperature (Halmann \& Steinfeld 2006). An increase in gasifier pressure increases the temperature of compressed air results a rise in gasifier temperature. The heating value is determined at the gasifier temperature and products are cooled to reference temperature of 298.15 K with a theoretically correct air fuel ratio. The heating value of syngas increases with increase in gasifier pressure but decreases with an increase in both relative air-fuel ratio and steam-fuel ratio. Hydrogen content in syngas decreases at a steady rate with increase in relative air-fuel ratio, and thus the heating value of gas decreases with increase in relative airfuel ratio.
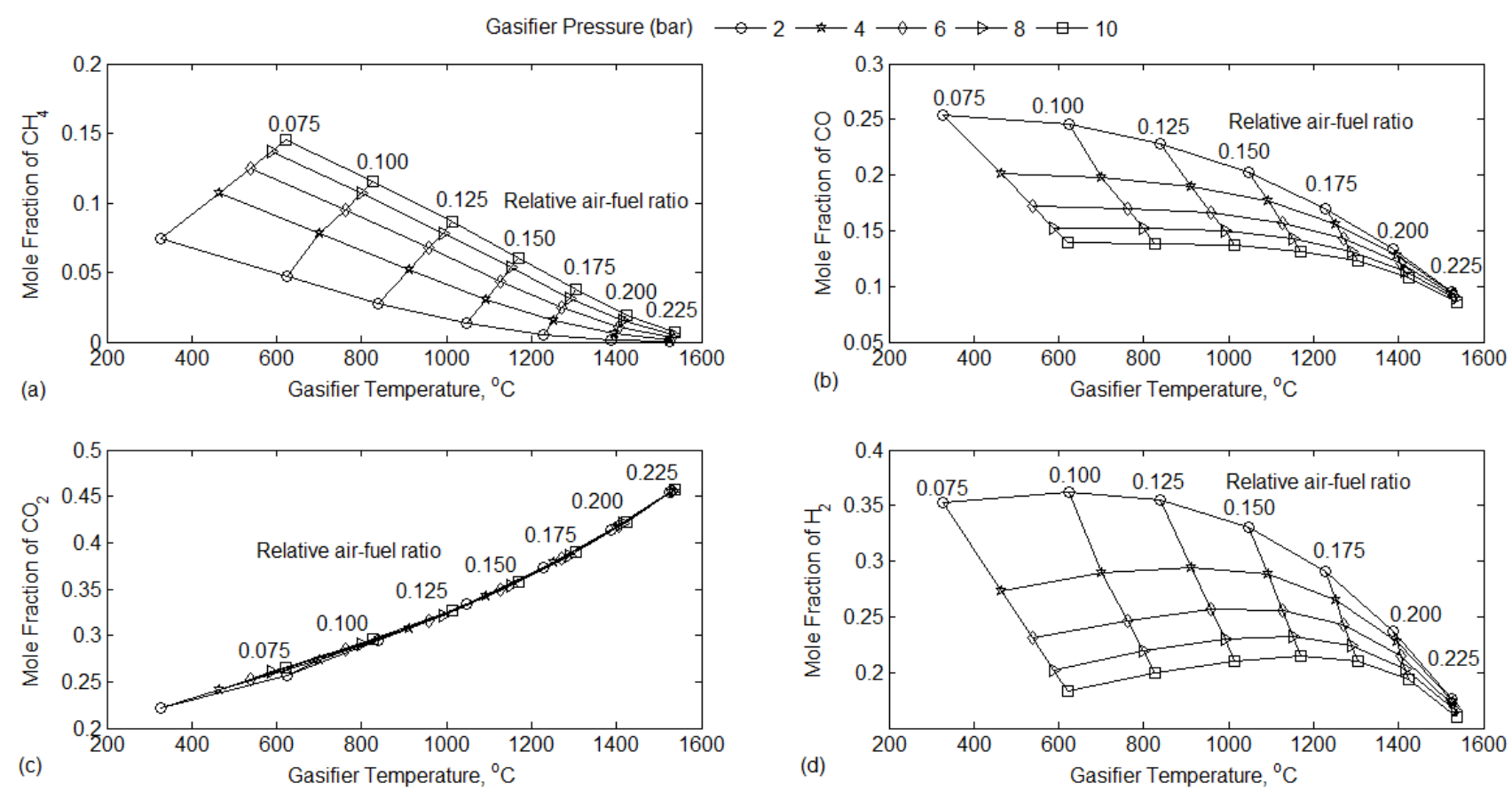

Figure 3 Gasification with steam-fuel ratio of 0.25 and with no flue gas ratio 
Now on simulating the proposed gasification cycle with integrated full combustion and partial oxidation systems, plots were obtained for varying gasifier pressure, relative air-fuel ratio, steam-fuel ratio, and a new parameter called gas-fuel ratio. Flue gas-fuel ratio is defined as the ratio of flue gas from coal based thermal power plants with fuel input into the gasifier. Figure 4 presents the simulation results for coal gasification with steam fuel ratio as 0.25 and varying flue gas-fuel ratio as $0.25,0.5,0.75$ and 1.0 . Increase in gas fuel ratio is processed by increasing the flue gas supply from thermal power plant with constant fuel supply in the gasifier. Higher the flue gas supply for constant fuel, better is the combustion and thus the composition of syngas decreases as fuel supply is maintained constant with increase in gas fuel ratio. As well increase in gasifier pressure increase the gasifier temperature drastically due to high moment of air particles at elevated pressure. Similarly Figure 5, Figure 6 and Figure 7 present results for coal gasification with steam fuel ratio as $0.50,0.75 \& 1.00$ and varying gas-fuel ratios. However it's also observed from the results that for constant pressure, gas fuel ratio, mole composition of methane, carbon monoxide and hydrogen tends to decrease drastically for increase in steam fuel ratio as the fuel composition fed is reduced.
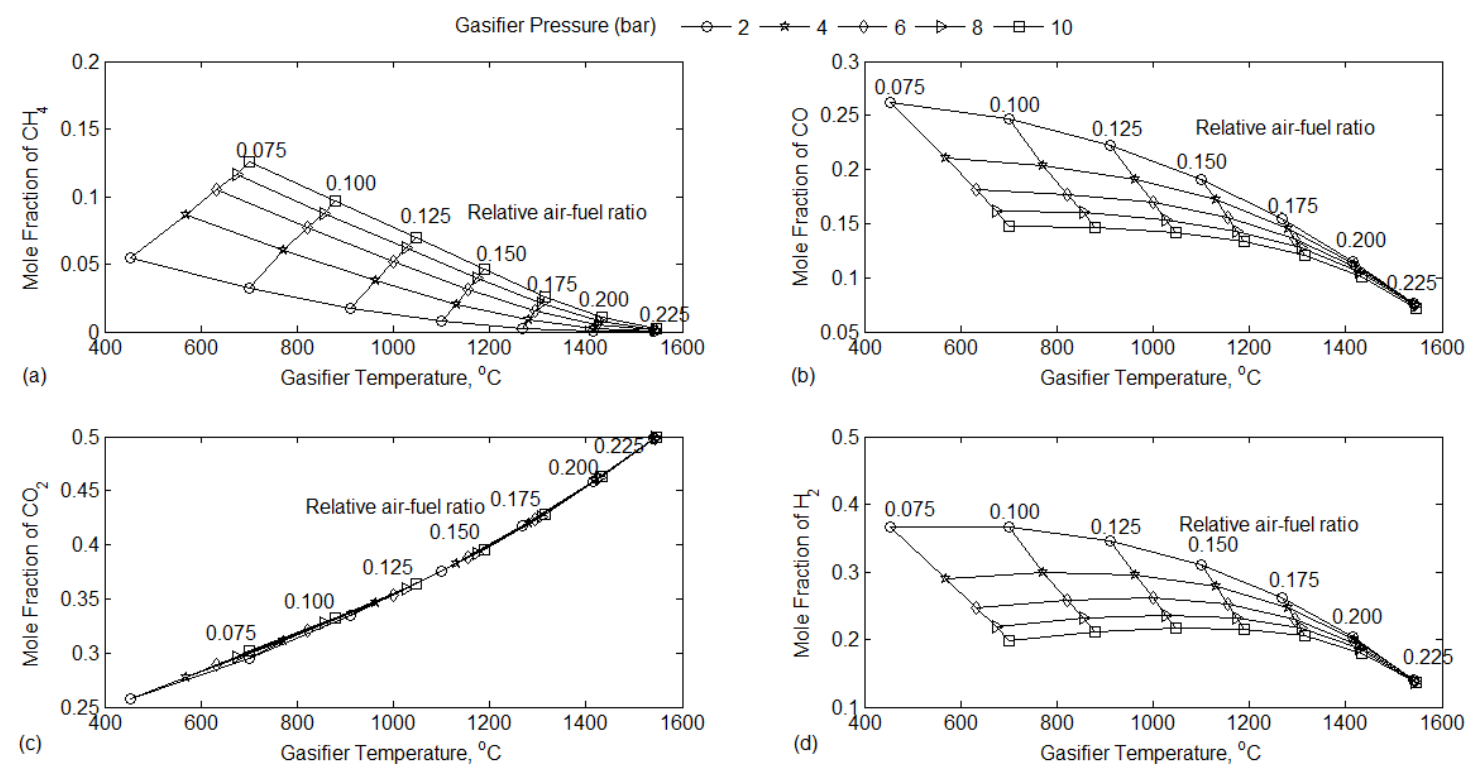

Figure 4 Gasification with steam-fuel ratio of 0.25 and flue gas-fuel ratio of 0.25 . 

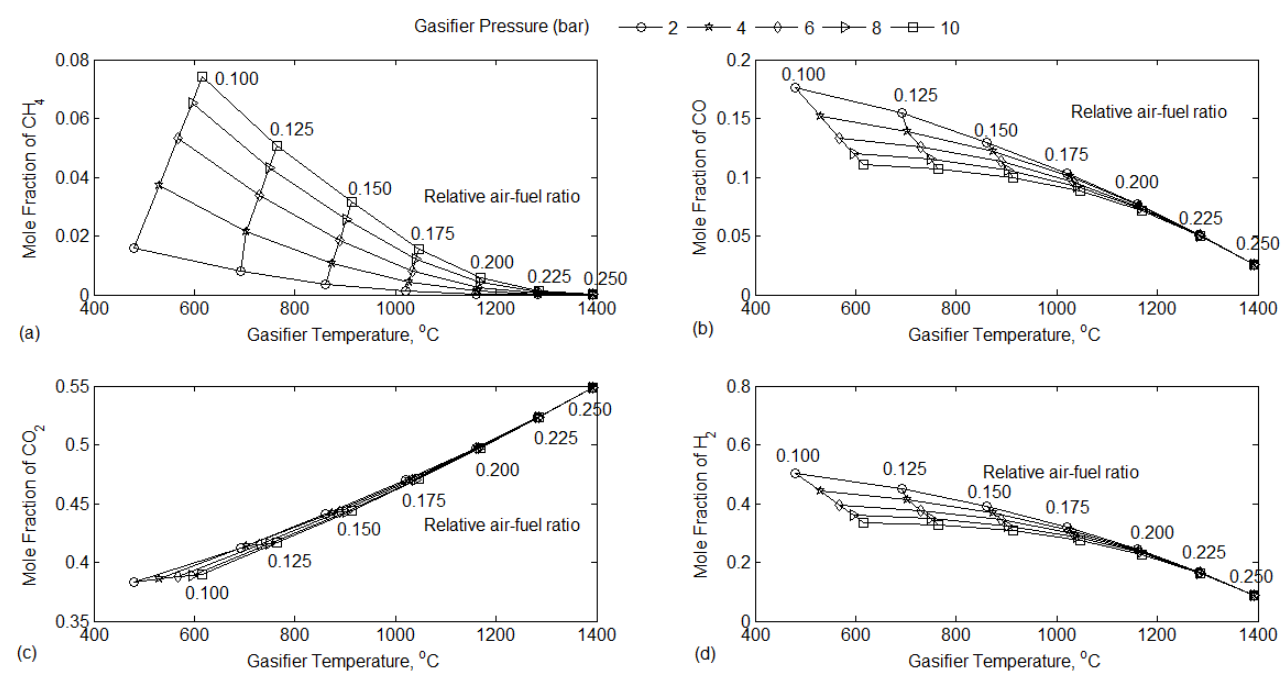

Figure 5 Gasification with steam-fuel ratio of 0.50 and flue gas-fuel ratio of 0.25 .
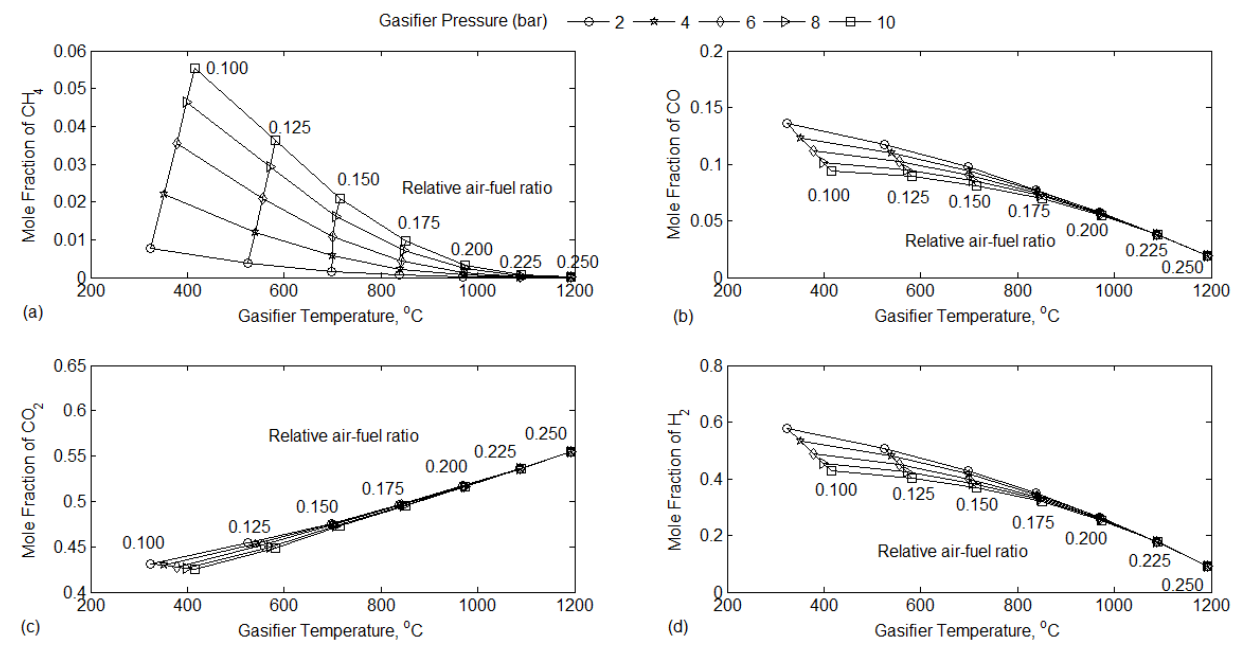

Figure 6 Gasification with steam-fuel ratio of 0.75 and flue gas-fuel ratio of 0.25 .
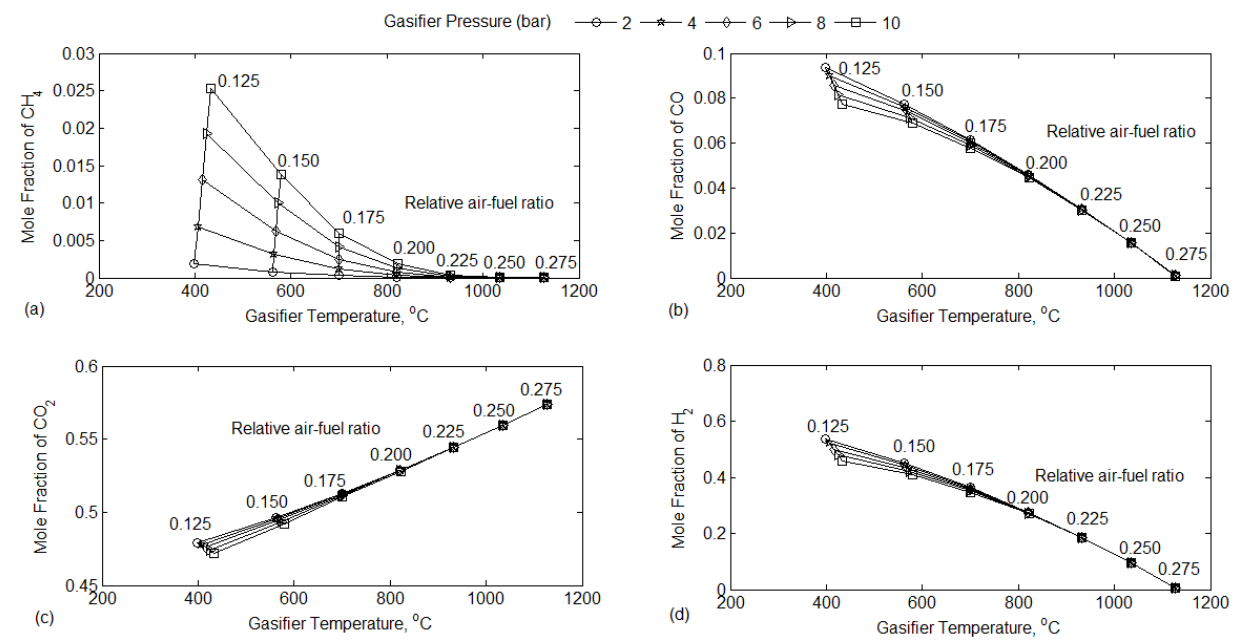

Figure 7 Gasification with steam-fuel ratio of 1.00 and flue gas-fuel ratio of 0.25 . 
Simulated results for gasifier pressure of 2 bar and steam-fuel ratio of 0.25 presented the results with highest mole fraction for various combinations of relative air-fuel ratio and gas fuel ratio. For introduction of exhaust flue gas with atmospheric air, results of mole fraction of syngas components were nearly close to that obtained by gasification using air only. It was also observed that variation in gas-fuel ratio doesn't affect mole fractions of CO and $\mathrm{H}_{2}$ significantly. Figure 8 presents the result for effect on gasification temperature with varying relative air-fuel ratio for different gas-fuel ratios at gasifier pressure of 2 bar and steam-fuel ratio of 0.25 . Mixture of coal fuel with air shows a steady increase in temperature with increase in relative air-fuel ratio irrespective of gas fuel ratio, as flue gas is not taken into account in the case. The excess supply of air contributes towards combustion and increases the temperature of the gasifier. Whereas mixture of coal fuel with air and flue gas increase in gas fuel ratio increases the flue gas concentration which enters the gasifier with high temperature and results in increase in gasifier temperature (Taba et. al, 2012).
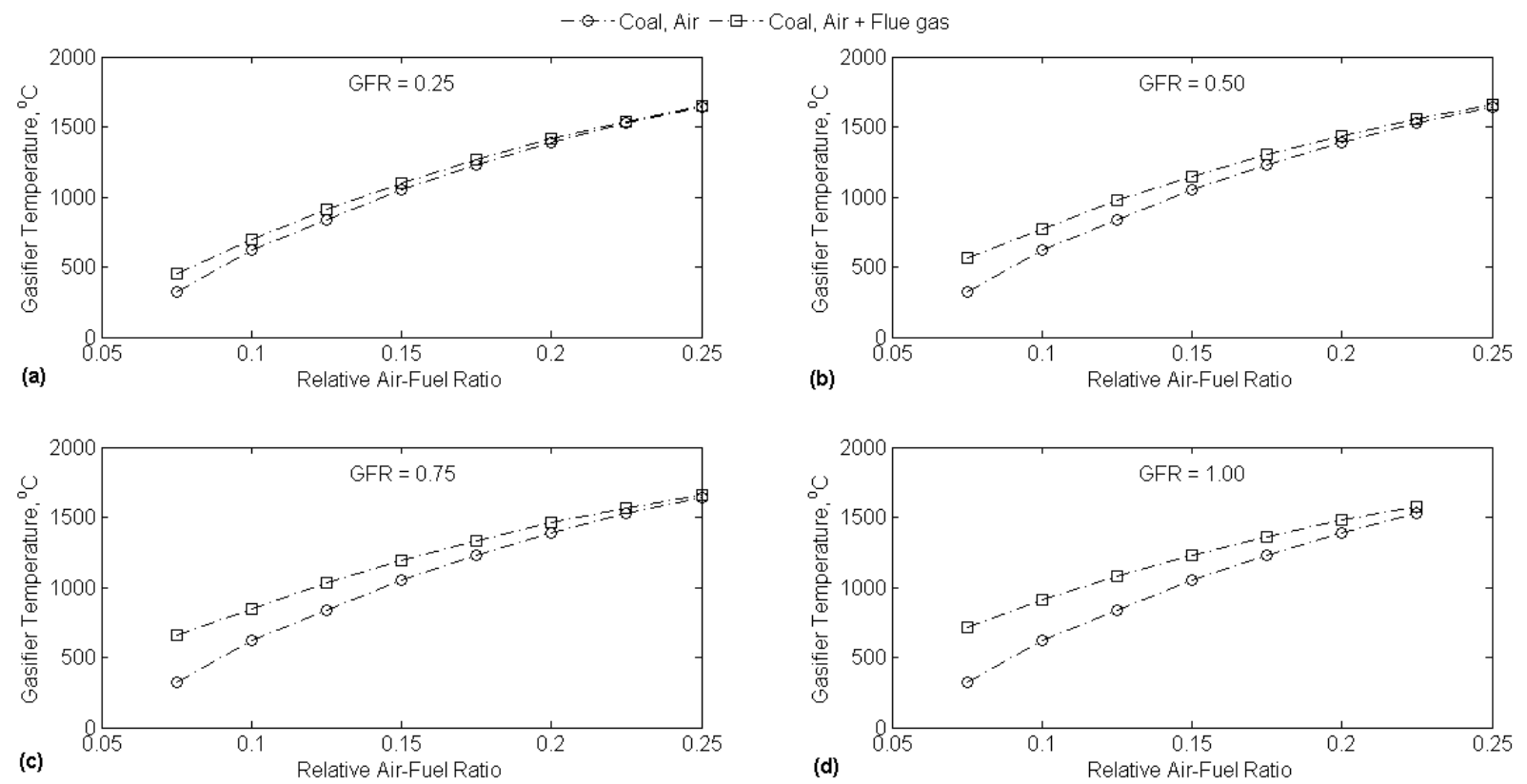

Figure 8 Variation in gasification temperature for gasifier pressure of 2 bar and steam-fuel ratio of 0.25 . 
Figure 9 presents the effect on mole fraction of gases at gas-fuel ratio of 0.25 with gasifier pressure of 2 bar and steam-fuel ratio of 0.25 . It's evident from the mole fraction composition graph of 2 bar pressure, 0.25 steam fuel ratio and 1.0 flue gas fuel ratio that with increase in relative air fuel ratio the percentage of oxygen supply for combustion increases which improves the burning and tends to decrease methane, carbon monoxide and hydrogen as excess oxygen combine with carbon dioxide and increase its composition alone. For every composition of syngas, with mixture of flue gas along with air, there is slight increase and decrease in the value of mole fraction, this occurs due to mixture of flue gas, as they add on to the syngas mixture.

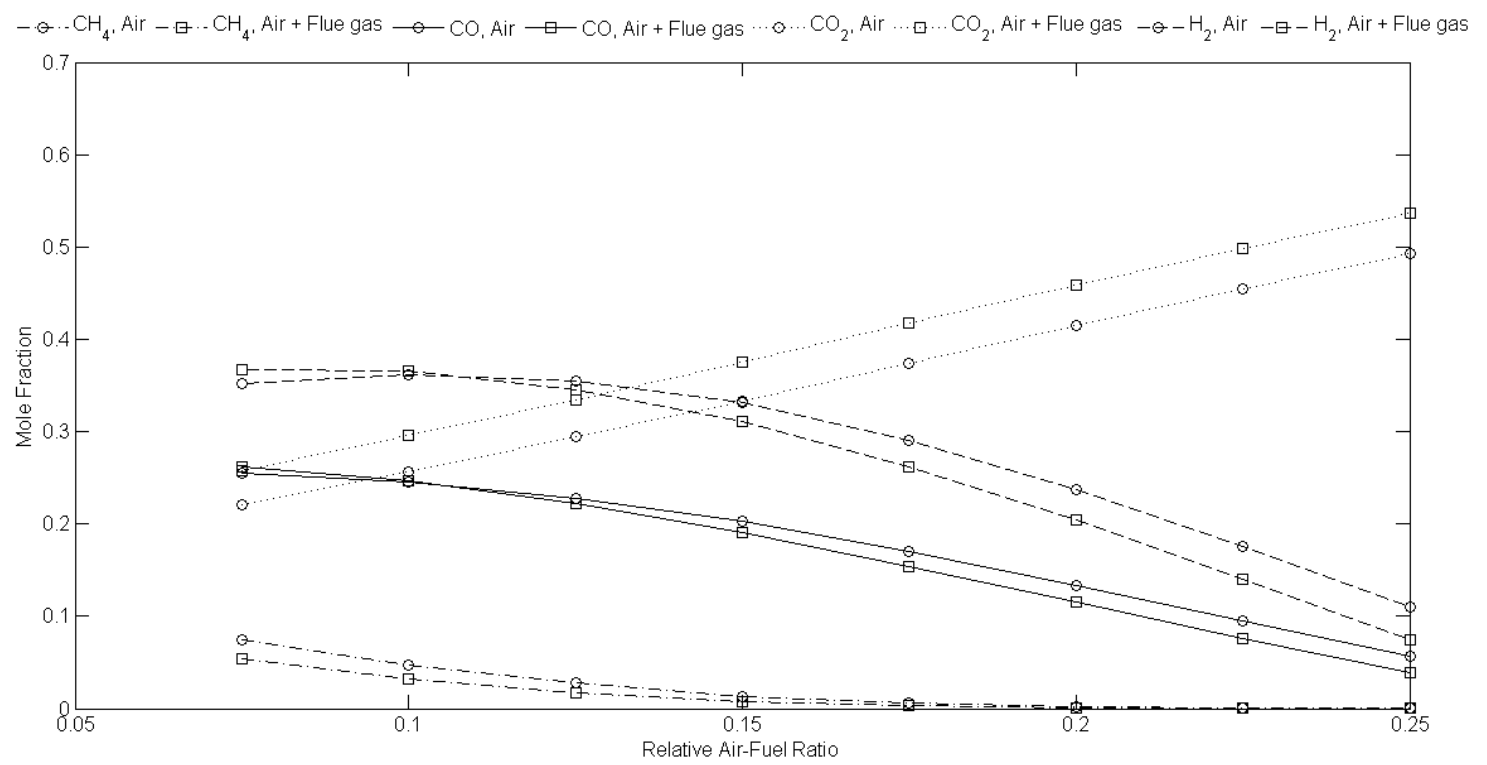

Figure 9 Variation in mole fraction of gases for gasifier pressure of 2 bar, flue gas-fuel ratio of 0.25 and steam-fuel ratio of 0.25 .

Inferring from the above results, cold-gas efficiency and heating value of syngas produced have been calculated and tabulated in Table 2 and Table 3 respectively. First column indicates the type of fuel (example: Coal). Column "air" indicates the efficiency and heating value for gasification using air while column "gas-fuel ratio" indicates the results for gasification using air with flue gas at different gas-fuel ratios mentioned in the table 2 . The optimum conditions are found to be as gasifier pressure of 2 bar, relative air-fuel ratio of 0.10 
and steam-fuel ratio of 0.25 . In the present work, coal is the primary input for the system and as an outcome of the proposed system, syngas is produced. Thus only the heating value of syngas produced is given in Table 3 .

Table 2 Cold gas efficiency (\%) at optimum conditions.

\begin{tabular}{|l|c|c|c|c|c|}
\hline \multirow{2}{*}{ Fuel } & \multirow{2}{*}{ Air } & \multicolumn{4}{|c|}{ Flue Gas - Fuel Ratio } \\
\cline { 3 - 6 } & & $\mathbf{0 . 2 5}$ & $\mathbf{0 . 5}$ & $\mathbf{0 . 7 5}$ & $\mathbf{1 . 0}$ \\
\hline Coal & 79.93 & 75.48 & 70.63 & 65.53 & 63.07 \\
\hline
\end{tabular}

Table 3 Heating value $(\mathrm{kJ} / \mathrm{kg})$ at optimum conditions.

\begin{tabular}{|c|c|c|c|c|c|}
\hline \multirow{2}{*}{ Fuel } & \multirow{2}{*}{ Air } & \multicolumn{4}{|c|}{ Gas - Fuel Ratio } \\
\cline { 3 - 6 } & & $\mathbf{0 . 2 5}$ & $\mathbf{0 . 5}$ & $\mathbf{0 . 7 5}$ & $\mathbf{1}$ \\
\hline Coal & 26028.67 & 24578.62 & 22999.04 & 21338.68 & 20538.26 \\
\hline
\end{tabular}

Cold gas efficiency is defined as the efficiency of potential energy of syngas produced with respect to the total energy input for production of syngas. Heating value is defined as the amount of heat released during the combustion of a unit mass of the gas. Table 4 present results for combustion of $1 \mathrm{~kg}$-mol of filtered syngas at various gas-fuel ratios with gasifier pressure of 2 bar and steam-fuel ratios of 0.25 for coal gasification and co-gasification, and 0.2 for solid waste gasification. For full combustion system and partial oxidation system, total fuel input is $1 \mathrm{~kg}$-mol, while for integrated full combustion and partial oxidation systems, total fuel input is $2 \mathrm{~kg}$-mol, $1 \mathrm{~kg}$-mol of coal in full combustion cycle and $1 \mathrm{~kg}$-mol of fuel in gasifier. The overall efficiencies for full combustion system and partial oxidation system have been considered as $37 \%$ and $30 \%$ respectively.

For individual cycles of full combustion and partial oxidation, the amount of $\mathrm{CO}_{2}$ released per kg-mol of fuel was found to be very high compare to that obtained for integrated cycle. Increment in steam-fuel ratio also affects the temperature of reactor bed. Increment in both 
relative air-fuel ratio and steam-fuel ratio decreases mole fraction of major components of syngas.

Table 4 Results for emissions and overall efficiency.

\begin{tabular}{|c|c|c|c|c|}
\hline Fuel & Gas-Fuel Ratio & $\begin{array}{c}\mathrm{CO}_{2} \\
(\mathrm{~kg} / \mathrm{kg}-\mathrm{mol} \text { of fuel })\end{array}$ & $\begin{array}{c}\mathrm{CO}_{2} \\
(\mathrm{~kg} / \mathrm{kWh})\end{array}$ & $\begin{array}{c}\text { Overall Efficiency } \\
(\%)\end{array}$ \\
\hline \multicolumn{5}{|c|}{ Full combustion system } \\
\hline Coal & - & 10.03 & 3.716 & 37.00 \\
\hline \multicolumn{5}{|c|}{ Partial oxidation system } \\
\hline Coal & - & 6.46 & 1.521 & 30.00 \\
\hline \multicolumn{5}{|c|}{ Integrated full combustion and partial oxidation system } \\
\hline \multirow{4}{*}{ Coal } & 0.25 & 3.25 & 0.743 & 33.96 \\
\hline & 0.50 & 3.28 & 0.769 & 34.08 \\
\hline & 0.75 & 3.30 & 0.794 & 34.20 \\
\hline & 1.00 & 3.31 & 0.807 & 34.27 \\
\hline
\end{tabular}

The content of $\mathrm{H}_{2}, \mathrm{CO}$, and $\mathrm{CH}_{3}$ in syngas influences the heating value of the syngas. The heating value of syngas is high at relatively lower air-fuel ratios. The increase in steam-fuel ratio in gasifier enhances the shift reaction in which carbon monoxide converts into carbon dioxide with the presence of steam and rise in both hydrogen and carbon dioxide contents are observed with the expense of carbon monoxide. This should be noted that there is no significant influence of gasifier pressure on gas composition. As per the obtained results, proposed integrated full combustion and partial oxidation cycle presents itself as a potential solution. Although the mole fraction of components of syngas doesn't vary significantly with introduction of exhaust flue gas, heating value and cold-gas efficiency indicates the decreasing quality of produced gas with increase in gas-fuel ratio. With increase in gas-fuel ratio, gasifier temperature increases with increase in carbon dioxide content. While, carbon 
monoxide, hydrogen and methane content of produced gas reduces. This can be accounted with the fact that exhaust flue gas from power plants has high percentage of $\mathrm{CO}_{2}$ that influences the mole fraction of other gases and gasifier temperature. Although the cold gas efficiency and heating value also reduces with introduction of flue gas, the carbon credit of proposed system was found to be nearly half of that from conventional coal based power plants. Also, the exhaust with zero sulphur content was obtained.

\section{CONCLUSIONS}

The research objective of the current article focuses on resolving the problem of sustainable power production using coal based thermal power plant by integrating gasification technologies to the system. Thus the authors proposed and analyzed an integrated full combustion and partial oxidation system, MATLAB based simulations were done with varying gasifier pressure, air-fuel ratio, steam-fuel ratio and gas-fuel ratio. The proposed cycle presents itself feasible and well suitable for its application in coal based thermal power plants, providing potential towards supplementary power generation and cleans exhaust. The important finding was that the system exhibit optimum performance of gasification system at gasifier pressure of 2 bar, air-fuel ratio of 0.1 , steam-fuel ratio of 0.25 and flue gas-fuel ratio of 1.00 . The cold-gas efficiency decreases steadily from $79.93 \%$ for gasification process using air to $63.07 \%$ with increasing gas-fuel ratio for gasification process through proposed integrated cycle, and heating value of syngas decreases from $26028.67 \mathrm{~kJ} / \mathrm{kg}$ to 20538.26 $\mathrm{kJ} / \mathrm{kg}$ respectively. But, through the integrated circuit, decrease in the amount of $\mathrm{CO}_{2}$ released per kg-mol of fuel was observed to be nearly one-third of the amount of $\mathrm{CO}_{2}$ released per $\mathrm{kg}$ mol of fuel from coal based thermal power plants. Also, zero sulphur content was observed in conventional gasification cycle and proposed cycle, while $0.03 \mathrm{~kg}$ of $\mathrm{SO}_{2}$ emission was observed from conventional coal based thermal power plants. The author suggests that in 
future any experimental analysis of coal thermal power plant using the above proposed method would ensure real time application for clean power production.

\section{REFERENCES}

Brar, J.S., Singh, K., Wang, J. \& Kumar, S. 2012. Cogasification of coal and biomass: a review. International Journal of Forestry Research.

Bridgwater, A.V. 2003. Renewable fuels and chemicals by thermal processing of biomass. Chemical Engineering Journal, 91(2-3): 87-102.

Chen, J., Yang, S. \& Qian, Y. 2019. A novel path for carbon-rich resource utilization with lower emission and higher efficiency: An integrated process of coal gasification and coking to methanol production. Energy 177: 304-318.

Corella, J. \& Toledo, M. 2008. Modelling a CFB Biomass Gasifier. Part I: Model Formulation. Progress in Thermochemical Biomass Conversion: 333.

De Micco, G., Fouga, G.G. \& Bohé, A.E. 2010. Coal gasification studies applied to $\mathrm{H}_{2}$ production. International Journal of Hydrogen Energy 35(11): 6012-6018.

Eftekhari, A.A., Van Der Kooi, H. \& Bruining, H. 2012. Exergy analysis of underground coal gasification with simultaneous storage of carbon dioxide. Energy 45(1): 729-745.

Furusawa, Y., Taguchi, H., Ismail, S.N., Thangavel, S., Matsuoka, K. \& Fushimi, C. 2019. Estimation of cold gas efficiency and reactor size of low-temperature gasifier for advanced-integrated coal gasification combined cycle systems. Fuel Processing Technology 193: 304-316.

Gutierrez, M.C., Cukierman, A.L. \& Lemcoff, N.O. 1987. Kinetic study of the reaction of a subbituminous coal char with oxygen. Reactivity of Solids 4(3): 227-236.

Halmann, M. and Steinfeld, A., 2006. Fuel saving, carbon dioxide emission avoidance, and syngas production by tri-reforming of flue gases from coal-and gas-fired power stations, and by the carbothermic reduction of iron oxide. Energy 31(15): 3171-3185. 
Han, X., Chen, N., Yan, J., Liu, J., Liu, M. \& Karellas, S. 2019. Thermodynamic analysis and life cycle assessment of supercritical pulverized coal-fired power plant integrated with No. 0 feedwater pre-heater under partial loads. Journal of Cleaner Production 233: 11061122.

Hu, Z., Peng, Y., Sun, F., Chen, S. and Zhou, Y., 2021. Thermodynamic equilibrium simulation on the synthesis gas composition in the context of underground coal gasification. Fuel, 293: 120-462.

Huynh, H., Clements, A.G., Szuhánszki, J., Gale, W.F., Ma, L., Ingham, D.B. \& Pourkashanian, M. 2019. Investigation of particle radiation and its effect on NO prediction in a pilot-scale facility for both air and oxy-coal combustion. Fuel, 250: 254-264.

Kong, H., Kong, X., Wang, J. \& Zhang, J. 2019. Thermodynamic analysis of a solar thermochemical cycle-based direct coal liquefaction system for oil production. Energy 179: $1279-1287$.

Lapuerta, M., Hernández, J.J., Pazo, A. \& López, J. 2008. Gasification and cogasification of biomass wastes: Effect of the biomass origin and the gasifier operating conditions. Fuel Processing Technology 89(9): 828-837.

Li, W., Yu, Z. and Guan, G., 2021. Catalytic coal gasification for methane production: A Review. Carbon Resources Conversion (4): 89-99.

Liang, C., Lyu, Q., Na, Y. \& Wang, X. 2019. Gasification of preheated coal: Experiment and thermodynamic equilibrium calculation. Journal of the Energy Institute, 92(4): 10051013.

Machin, E.B., Pedroso, D.T., Machín, A.B., Acosta, D.G., dos Santos, M.I.S., de Carvalho, F.S., Pérez, N.P., Pascual, R. and de Carvalho Júnior, J.A., 2021. Biomass integrated gasification-gas turbine combined cycle (BIG/GTCC) implementation in the 
Brazilian sugarcane industry: Economic and environmental appraisal. Renewable Energy, 172: 529-540.

Ochoa, J., Cassanello, M.C., Bonelli, P.R. \& Cukierman, A.L. 2001. $\mathrm{CO}_{2}$ gasification of Argentinean coal chars: a kinetic characterization. Fuel Processing Technology 74(3): 161176.

Pio, D.T., Tarelho, L.A.C. and Pinto, P.C.R., 2020. Gasification-based biorefinery integration in the pulp and paper industry: A critical review. Renewable and Sustainable Energy Reviews, 133: 110-210.

Rezaiyan, J. \& Cheremisinoff, N.P. 2005. Gasification technologies: a primer for engineers and scientists. CRC press.

Sarafraz, M.M., Jafarian, M., Arjomandi, M. \& Nathan, G.J. 2017. Potential use of liquid metal oxides for chemical looping gasification: a thermodynamic assessment. Applied Energy 195: 702-712.

Sarafraz, M.M., Jafarian, M., Arjomandi, M. \& Nathan, G.J. 2017. The relative performance of alternative oxygen carriers for liquid chemical looping combustion and gasification. International Journal of Hydrogen Energy 42(26): 16396-16407.

Sarafraz, M.M., Jafarian, M., Arjomandi, M. \& Nathan, G.J. 2019. The thermo-chemical potential liquid chemical looping gasification with bismuth oxide. International Journal of Hydrogen Energy, 44(16): 8038-8050.

Srinivas, T., Reddy, B.V. \& Gupta, A.V.S.S.K.S. 2012. Thermal performance prediction of a biomass based integrated gasification combined cycle plant. Journal of Energy Resources Technology 134(2).

Srinivas, T., Gupta, A.V.S.S.K.S. \& Reddy, B.V. 2009. Thermodynamic equilibrium model and exergy analysis of a biomass gasifier. Journal of Energy Resources Technology 131(3). 
Taba, L.E., Irfan, M.F., Daud, W.A.M.W. and Chakrabarti, M.H., 2012. The effect of temperature on various parameters in coal, biomass and $\mathrm{CO}$-gasification: A review. Renewable and Sustainable Energy Reviews, 16(8): 5584-5596.

Tian, Y., Zhou, X., Lin, S., Ji, X., Bai, J. and Xu, M., 2018. Syngas production from airsteam gasification of biomass with natural catalysts. Science of the Total Environment, 645: 518-523.

Wang, X., Zhu, Z., Wang, K., Yu, K. \& Lyu, Q. 2019. Experimental study of pilot-scale CFB gasification: Effect of gasifying agent and coal feeding modes on the gasification performance. Fuel, 251: 603-610.

Warnecke, R. 2000. Gasification of biomass: comparison of fixed bed and fluidized bed gasifier. Biomass and Bioenergy 18(6): 489-497.

Xiang, Y., Cai, L., Guan, Y., Liu, W., He, T. \& Li, J. 2019. Study on the biomass-based integrated gasification combined cycle with negative $\mathrm{CO}_{2}$ emissions under different temperatures and pressures. Energy 179: 571-580. 